\title{
Author Correction: Methylation of LINE-1 in cell-free DNA serves as a liquid biopsy biomarker for human breast cancers and dog mammary tumors
}

\author{
Kang-Hoon Lee, Tae-Jin Shin, Wan-Hee Kim \& Je-Yoel Cho \\ Correction to: Scientific Reports https://doi.org/10.1038/s41598-018-36470-5, published online 17 January 2019
}

Soo-Youn Lee was incorrectly listed as an author in the original version of this Article and has now been removed from the author list. In addition, the Acknowledgements section in the original version of this Article was incomplete and now reads:

"This research was supported by the Bio \& Medical Technology Development Program of the National Research Foundation (NRF) funded by the Ministry of Science and ICT (\#2016M3A9B6026771) and partially by (\#2016R1A6A3A11932951). The authors wish to thank Dr. Sun-Young Hwang at the Haemaru referral animal hospital for assistance in providing some of the clinical specimens.

The authors also wish to thank Isaac Kim, Jai Min Ryu, Hee Jun Choi, Jae-Myung Kim, Se Kyung Lee, Jonghan Yu, Seok Won Kim, Seok Jin Nam, Jeong Eon Lee and Soo-Youn Lee at the Samsung Medical Center for assistance in providing the valuable clinical specimens."

These errors have now been corrected in the HTML and PDF versions of the Article, and in the accompanying supplementary material.

(i) Open Access This article is licensed under a Creative Commons Attribution 4.0 International License, which permits use, sharing, adaptation, distribution and reproduction in any medium or format, as long as you give appropriate credit to the original author(s) and the source, provide a link to the Creative Commons license, and indicate if changes were made. The images or other third party material in this article are included in the article's Creative Commons license, unless indicated otherwise in a credit line to the material. If material is not included in the article's Creative Commons license and your intended use is not permitted by statutory regulation or exceeds the permitted use, you will need to obtain permission directly from the copyright holder. To view a copy of this license, visit http://creativecommons.org/licenses/by/4.0/.

(C) The Author(s) 2019 